\title{
FAKTOR PENDORONG PERTUMBUHAN EKONOMI DAERAH DI INDONESIA
}

\author{
Agus Tri Basuki \\ Fakultas Ekonomi dan Bisnis \\ Universitas Muhammadiyah Yogyakarta \\ e-mail : agustribasuki@yahoo.coml
}

\begin{abstract}
This study aims to examine the role of fiscal policy and macro variables in encouraging regional economic growth in Indonesia. This study uses panel data regression using a sample of 18 provinces in Indonesia. Research supporting data sourced from the Indonesian Central Bureau of Statistics and the Ministry of Finance of the Republic of Indonesia from 20082017. The results showed that local government spending on education, health, agriculture, and fisheries and maritime affairs had a positive effect on economic growth, but the effect was less effective in promoting economic growth. To overcome the ineffective role of fiscal policy in promoting economic growth, the central and regional governments must change budgeting from a traditional approach to a budgeting approach to performance. Based on the regional financial management law, regional leaders have power over regional budget management, but in the use of the budget it must be used for the maximum welfare of the people. Meanwhile, the role of foreign investment in promoting economic growth is very low. The government's role in overcoming the low role of foreign investment is only to provide business permits for pro-labor-intensive foreign investment.
\end{abstract}

\begin{abstract}
ABSTRAK
Penelitian ini bertujuan untuk menguji peran kebijakan fiskal dan variabel makro dalam mendorong pertumbuhan ekonomi daerah di Indonesia. Penelitian ini menggunakan regresi data panel dengan menggunakan sampel dari 18 provinsi di Indonesia. Data pendukung penelitian bersumber dari Badan Pusat Statistik Indonesia dan Kementerian Keuangan Republik Indonesia tahun 2008-2017. Hasil penelitian menunjukkan bahwa belanja pemerintah daerah untuk pendidikan, kesehatan, pertanian, serta perikanan dan kelautan berpengaruh positif terhadap pertumbuhan ekonomi, namun pengaruhnya kurang efektif dalam mendorong pertumbuhan ekonomi. Untuk mengatasi tidak efektifnya peran kebijakan fiskal dalam mendorong pertumbuhan ekonomi, pemerintah pusat dan daerah harus mengubah penganggaran dari pendekatan tradisional menjadi pendekatan penganggaran menuju kinerja. Berdasarkan undang-undang pengelolaan keuangan daerah, pemimpin daerah memiliki kewenangan atas pengelolaan anggaran daerah, namun dalam penggunaan anggarannya harus digunakan untuk sebesar-besar kemakmuran rakyat. Sedangkan peran investasi asing dalam mendorong pertumbuhan ekonomi sangat rendah. Peran pemerintah dalam mengatasi rendahnya peran penanaman modal asing hanya memberikan izin usaha bagi penanaman modal asing yang pro padat karya.
\end{abstract}

Kata Kunci : pertumbuhan ekonomi daerah, belanja pemerintah, data panel, pembangunan ekonomi. 


\section{Buletin Ekonomi}

\section{PENDAHULUAN}

Proses pembangunan kawasan sering dikaitkan dengan peran penting pertumbuhan ekonomi, semakin besar pertumbuhan ekonomi menunjukan kawasan tersebut memiliki peranan penting dalam pembangunan ekonomi. Bagi negara-negara berkembang untuk mengejar ketertinggalan pembangunan ekonomi dibutuhkan peranan pemerintah yang lebih besar untuk mengisi kegiatan ekonomi. Pengeluaran dan kegiatan-kegiatan pemerintah yang semakin meningkat dinyatakan oleh Adoft Wagner dinamakan Law of Ever Increasing State Activities atau meningkatnya kegiatan-kegiatan Negara (Lamartina and Zaghini, 2011).

Hubungan antara belanja pemerintah dengan pertumbuhan ekonomi dapat dijelaskan dengan angka elastisitas. Angka elastisitas menunjukan seberapa besar pengaruh perubahan belanja pemerintah akan berpengaruh terhadap perubahan Pendapatan Domestik Bruto (Mangkoesoebroto, 2001). Menurut Wagner meningkatnya pengeluaran pemerintah disebabkan karena meningkatnya fungsi pembangunan, artinya semakin besar pengeluaran pemerintah dapat mendorong laju pembangunan ekonomi suatu negara. Berdasarkan perhitungan angka elastisitas tahun 2012 hingga 2017 dalam Tabel 1 dapat diduga peningkatan belanja pemerintah dapat meningkatkan Produk Domestik Bruto tetapi tambahan peningkatannya semakin menurun.

Tabel 1.

Hubungan antara Belanja Pemerintah dengan PDB (2010=100)

\begin{tabular}{ccccrrr}
\hline & \multicolumn{5}{c}{ (Milyar Rp) } & \multicolumn{3}{c}{$\begin{array}{c}\text { Rasio Belanja } \\
\text { Pemerintah } \\
\text { Tahun }\end{array}$} & $\begin{array}{c}\text { Belanja } \\
\text { Pemerintah }\end{array}$ & Perubahan & PDB & Perubahan PDB & Elatisitas \\
& & & & & 17.77 & - \\
\hline 2011 & $1,294,999$ & - & $7,287,635$ & & 19.30 & 0.43 \\
2012 & $1,491,410$ & 196,411 & $7,727,083$ & 439,448 & 20.24 & 0.55 \\
2013 & $1,650,564$ & 159,154 & $8,156,498$ & 429,415 & 20.75 & 0.67 \\
2014 & $1,777,183$ & 126,619 & $8,564,867$ & 408,369 & 22.09 & 0.45 \\
2015 & $1,984,100$ & 206,917 & $8,982,511$ & 417,644 & 22.22 & 0.90 \\
2016 & $2,095,700$ & 111,600 & $9,433,034$ & 450,523 & 22.97 & 0.61 \\
2017 & $2,276,479$ & 180,779 & $9,911,289$ & 478,255 & &
\end{tabular}

Sumber : BPS 2012, 2014, 2016, 2018 (data diolah)

Menurut Wagner peningkatan pengeluaran pemerintah karena meningkatnya fungsi pertahanan, meningkatnya fungsi kesejahteraan, meningkatnya fungsi perbankan, dan meningkatnya fungsi pembangunan. Menurut Peacock dan Wiseman pengeluaran pemerintah semakin meningkat karena social disturbance seperti gangguan keamanan dan depresi ekonomi. Wagner tidak memberikan batas toleransi antara pengeluaran negara terhadap PDB, sedangkan Clark memberikan batas toleransi untuk pengeluran negara kurang lebih 25 persen dari PDB (Soetrisno, 1981). Apabila batas 25 persen PDB terlampaui maka akan timbul inflasi yang mengacaukan kehidupan ekonomi. Berdasarkan perhitungan rasio pengeluaran pemerintah terhadap PDB Indonesia sampai tahun 2017 masih dibawah ambang batas toleransi yaitu 22,97 persen. 


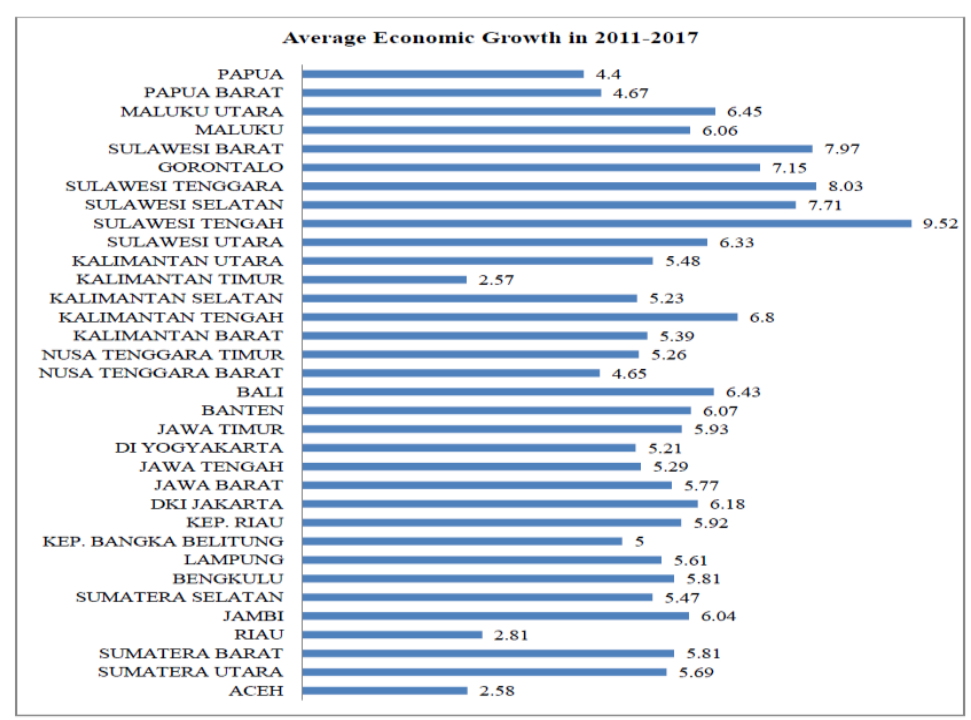

Gambar 1. Rerata Pertumbuhan ekonomi 2011-2017

Gambar 1 menunjukkan rata-rata pertumbuhan ekonomi tahun 2011-2017 tertinggi dicapai oleh provinsi Sulawesi Utara $(9,52 \%)$, provinsi Sulawesi Tenggara $(8,03 \%)$ dan provinsi Sulawesi Barat (7,97\%). Sedangkan rata-rata pertumbuhan ekonomi tahun 20112017 terendah dicapai oleh provinsi Kalimantan Timur (2,57), Provinsi Aceh $(2,58 \%)$ dan provinsi Riau $(2,81 \%)$. Provinsi Kalimantan Timur, provinsi Aceh dan provinsi Riau adalah daerah terkaya di Indonesia, namun rata-rata pertumbuhan ekonomi terendah di Indonesia. Sedangkan provinsi Sulawesi Utara, provinsi Sulawesi Tenggara dan provinsi Sulawesi Barat bukan daerah kaya namun rata-rata pertumbuhan ekonominya menempati urutan tertinggi di Indonesia. Fenomena ini cukup menarik untuk diteliti faktor-faktor apa yang mendorong pertumbuhan ekonomi suatu daerah. Berdasarkan hasil fenomena data, sangat menarik untuk meneliti faktor-faktor apa yang mempengaruhi pertumbuhan ekonomi di beberapa propinsi di Indonesia.

Kebijakan fiskal adalah suatu kebijakan ekonomi yang dilakukan oleh pemerintah dalam mengelola keuangan negara dengan tujuan mengarahkan kondisi perekonomian menjadi lebih baik. Kebijakan fiskal yang lazim dilakukan pemerintahan daerah adalah penyusunan Anggaran Pendapatan dan Belanja Daerah (APBD). Anggaran Pendapatan dan Belanja Daerah (APBD) disusun sesuai dengan kebutuhan penyelenggaraan pemerintah dan kemampuan pendapatan daerah. Penyusunan APBD ini berpedoman pada Rencana Kerja Pemerintah Daerah (RKPD) dalam rangka mewujudkan pelayanan kepada masyarakat untuk tercapainya tujuan bernegara. APBD mempunyai fungsi otorisasi, perencanaan, pengawasan, alokasi, distribusi, dan stabilisasi (Indra, 2006). Kebijakan fiskal menduduki posisi strategis dalam kebijakan ekonomi makro. kebijakan fiscal melalui pengeluaran pemerintah dapat mempengaruhi laju pertumbuhan ekonomi (Basri,1995).

Selain kebijakan fiskal melalui perencanaan APBD dalam mempengaruhi kondisi perekonomian, investasi juga dapat diandalkan untuk menciptakan strategi pembangunan menguatkan sendi-sendi perekonomian nasional. Setiap upaya pembangunan ekonomi daerah mempunyai tujuan utama untuk meningkatkan jumlah dan jenis peluang kerja untuk masyarakat daerah (Arsyad, 2014). Untuk mencapai tujuan tersebut, pemerintah daerah dan masyarakat bersama-sama mengambil inisiatif membangun daerah. Sebagian ahli ekonomi memandang bahwa pembentukan investasi merupakan motor penggerak dalam mendorong pertumbuhan dan pembangunan ekonomi suatu daerah. Ketika pengusaha atau individu atau pemerintah melakukan investasi, maka ada sejumlah modal yang ditanam atau dikeluarkan, 


\section{Buletin Ekonomi}

atau ada sejumlah pembelian barang-barang yang tidak dikonsumsi, tetapi digunakan untuk produksi, sehingga menghasilkan barang dan jasa dalam meningkatan Produk Domestik Bruto. Argumen yang mendukung penanaman modal asing salah satu pendorong pertumbuhan ekonomi berasal dari pendapat neoklasik tradisional mengenai penentuan pertumbuhan ekonomi. Menurut analisis ini penanaman modal asing merupakan sesuatu yang dapat mengisi celah yang ada antara tabungan yang dihimpun dari dalam negeri, cadangan devisa, penerimaan pemerintah dan keahlian di satu pihak dan jumlah yang dibutuhkan untuk mencapai sasaran pembangunan di pihak lain (Todaro, 2000). Bila negara yang bersangkutan dapat mengisi kekurangan tersebut dengan sumber-sumber keuangan luar negeri maka negara tersebut akan dapat mencapai sasaran pertumbuhannya dengan baik. Dengan demikian penanaman modal asing memiliki peran dalam menyumbang pertumbuhan ekonomi suatu negara.

Penelitian mengenai hubungan antara jumlah penduduk miskin terhadap pertumbuhan ekonomi dilakukan Dao (2012), Sylwester (2000) and Rustam (2013), Hasil temuan penelitian Dao menyimpulkan jumlah penduduk miskin berpengaruh positif dan signifikan terhadap pertumbuhan ekonomi. Penelitian Sylwester menyimpulkan bahwa jumlah penduduk miskin memiliki pengaruh negatif terhadap pertumbuhan ekonomi.

Penelitian mengenai hubungan antara pengeluaran pemerintah untuk pendidikan terhadap pertumbuhan ekonomi dilakukan Muthui, et. al (2013), Nworji, Okwu, et. al (2012) dan Mehana (2011) menyimpulkan bahwa pengeluaran pemerintah untuk pendidikan memiliki pengaruh positip terhadap pembangunan ekonomi.

Penelitian mengenai hubungan antara pengeluaran pemerintah untuk kesehatan terhadap pertumbuhan ekonomi dilakukan Al-Shatti (2014) dan Dada (2013). Penelitian tersebut menyimpulkan bahwa pengeluaran pemerintah untuk kesehatan memiliki pengaruh positip terhadap pertumbuhan ekonomi di beberapa negara.

Penelitian mengenai hubungan antara pengeluaran pemerintah untuk pertanian terhadap pertumbuhan ekonomi dilakukan Mursidah, dkk. (2017), Armas, at. al. (2012) dan Chidinma and Kemisola (2012). Penelitian ini menyimpulkan bahwa pengeluaran pemerintah untuk pertanian mendorong pertumbuhan ekonomi.

Penelitian mengenai hubungan antara pengeluaran pemerintah untuk perikanan dan kelautan terhadap pertumbuhan ekonomi dilakukan Huda, et. al. (2015), Novianti, et.al (2014). dan Agustine (2014). Hasil penelitian tersebut menyimpulkan bahwa pengeluaran pemerintah untuk perikanan dan kelautan dapat mendorong pertumbuhan ekonomi.

Penelitian mengenai hubungan antara Dana Alokasi Umum (DAU) terhadap pertumbuhan ekonomi dilakukan Tajuddin, et. al (2014), Ahmad (2011), dan Manik dan Hidayat, (2010). Hasil penelitian tersebut menyimpulkan bahwa Dana Alokasi Umum dapat mendorong pertumbuhan ekonomi.

Penelitian mengenai hubungan antara investasi asing terhadap pertumbuhan ekonomi dilakukan Kurt (2015) dan Abala (2014). Penelitian tersebut meyimpulkan bahwa penanaman modal asing dapat mendorong pertumbuhan ekonomi. Penelitian Oloni and Olabisi (2012) menyimpulkan bahwa penanaman modal asing justru menghambat pertumbuhan ekonomi.

Penelitian mengenai hubungan antara indek korupsi terhadap pertumbuhan ekonomi dilakukan grabova (2014), dan Mauro (1995). Penelitian Mauro menyimpulkan praktek korupsi (diukur melalui indeks korupsi), berupa pemberian dana untuk mempercepat sesuatu urusan (speed money) yang memungkinkan pelaku ekonomi terhindar dari penundaanpenundaan urusannya, dapat mendukung pertumbuhan apabila negara tersebut aturan birokrasinya sangat buruk. Hasil penelitian Grabova menyimpulkan bahwa indeks korupsi 


\section{Buletin Ekonomi}

memperlambat atau menurunkan pertumbuhan ekonomi, di samping juga menimbulkan ketidakadilan dan kesenjangan pendapatan masyaraka.

\section{METODE}

1. Data

Data yang digunakan dalam penelitian ini bersumber dari Biro Pusat Statistik Daerah Indonesia, Kementrian Keuangan Republik Indonesia dan Badan Perencana Pembangunan Daerah. Dalam penelitian ini menggunakan kasus 20 provinsi dari 34 provinsi yang ada di Indonesia dari tahun 2008 sampai dengan tahun 2017. Alasan dipilihnya 20 provinsi sebagai data penelitian karena hanya 20 provinsi dari 34 provinsi yang ada di Indonesia yang memiliki data lengkap.

2. Model Spesifikasi

Model regresi yang digunakan dalam penelitian ini adalah regresi data panel sebagai berikut ini:

\begin{tabular}{cl}
$\mathrm{GDRP}_{\mathrm{ti}}=$ & \multicolumn{1}{c}{$\mathrm{f}\left(\mathrm{POV}_{\mathrm{ti}}, \mathrm{GEE}_{\mathrm{ti}}, \mathrm{GEH}_{\mathrm{ti}}, \mathrm{GEM}_{\mathrm{ti}}, \mathrm{GEA}_{\mathrm{ti}}, \mathrm{DAU}_{\mathrm{ti}}, \mathrm{FDI}_{\mathrm{ti}}, \mathrm{OPN}_{\mathrm{ti}}\right)$} \\
Keterangan : & \\
GDRP & Produk Domestik Regional Bruto \\
POV & Jumlah Penduduk Miskin \\
GEE & Pengeluaran Pemerintah Untuk Pendidikan \\
GEH & Pengeluaran Pemerintah Untuk Kesehatan \\
GEM & Pengeluaran Pemerintah Untuk Kelautan dan Perikanan \\
GEA & Pengeluaran Pemerintah Untuk Pertanian \\
DAU & Dana Alokasi Umum \\
FDI & Investasi Asing Langsung \\
Opn & Opini BPK terhadap Laporan Pertanggungjawaban Keuangan Daerah
\end{tabular}

Dari persamaan diatas, koefisien yang menunjukan angka elastisitas $\beta$ yang berarti perubahan prosentasi variable independen akan mempengaruhi perubahan prosentase variable dependen. Angka $\beta=\%$ perubahan variable dependen dibagi dengan $\%$ perubahan variable independen. Koefisien ini dapat dicari dengan melakukan log (Gujarati, 2003) terhadap semua variable.

$$
\begin{aligned}
\log \left(\mathrm{GDRP}_{\mathrm{ti}}\right)= & \log \beta_{0}+\beta_{1} \log \left(\mathrm{POV}_{\mathrm{ti}}\right)+\beta_{2} \log \left(\mathrm{GEE}_{\mathrm{ti}}\right)+\beta_{3} \log \left(\mathrm{GEH}_{\mathrm{ti}}\right)+\beta_{4} \\
& \log \left(\mathrm{GEM}_{\mathrm{ti}}\right)+\beta_{5} \log \left(\mathrm{GEA}_{\mathrm{ti}}\right)+\beta_{6} \log \left(\mathrm{DAU}_{\mathrm{ti}}\right)+\beta_{7} \log \left(\mathrm{FDI}_{\mathrm{ti}}\right)+ \\
& \beta_{8} \mathrm{OPN}_{\mathrm{ti}}+\varepsilon_{\mathrm{t}}
\end{aligned}
$$

Meskipun komponen error $\varepsilon_{\mathrm{t}}$ bersifat homoskedastik, nyatanya terdapat korelasi antara $\varepsilon_{\mathrm{t}}$ dan $\varepsilon_{\mathrm{it}-\mathrm{s}}$ (equicorrelation), yakni :

$$
\operatorname{Corr}\left(\varepsilon_{\mathrm{it}}, \varepsilon_{\mathrm{i}(\mathrm{t}-1))}=\beta_{\mathrm{u}}^{2} /\left(\beta^{2}+\beta_{\mathrm{u}}^{2}\right)\right.
$$

Karena itu, metode OLS tidak bisa digunakan untuk mendapatkan estimator yang efisien bagi model random effects. Metode yang tepat untuk mengestimasi model random effects adalah Generalized Least Squares (GLS) dengan asumsi homoskedastik dan tidak ada cross-sectional correlation. 


\section{Buletin Ekonomi}

\section{ANALISIS DAN PEMBAHASAN}

Model yang dihasilkan dalam regresi data panel sebagai berikut model Common effect, model Fixed Effect dan model Random effect (Hsiao, 2014). Model common effects merupakan pendekatan data panel yang paling sederhana. Model ini tidak memperhatikan dimensi individu maupun waktu sehingga diasumsikan bahwa perilaku antar individu sama dalam berbagai kurun waktu. Model ini hanya mengkombinasikan data time series dan cross section dalam bentuk pool, mengestimasinya menggunakan pendekatan pooled least square. Model Fixed effects mengasumsikan bahwa terdapat efek yang berbeda antar individu. Perbedaan itu dapat diakomodasi melalui perbedaan pada intersepnya. Sedangkan random effects model (REM) adalah efek spesifik dari masing-masing individu diperlakukan sebagai bagian dari komponen error yang bersifat acak dan tidak berkorelasi dengan variabel penjelas yang teramati. Ketiga model regresi data panel dapat disajikan dalam tabel berikut :

Tabel 2

Hasil Regresi Data Panel

\begin{tabular}{|c|c|c|c|}
\hline $\begin{array}{l}\text { Variable Dependent } \\
\text { LOG(GDRP })_{t}\end{array}$ & None Effect & Fixed Effect & Random Effect. \\
\hline \multirow{2}{*}{$\mathrm{LOG}(\mathrm{POV})_{\mathrm{t}}$} & $0.645 * * *$ & $-0.292 * * *$ & 0.095 \\
\hline & $(19.251)$ & $(-4.899)$ & $(1.557)$ \\
\hline \multirow{2}{*}{$\mathrm{LOG}(\mathrm{GEE})_{\mathrm{t}}$} & $0.250 * * *$ & $0.034 * * *$ & $0.041 * * *$ \\
\hline & (7.243) & (4.723) & (4.648) \\
\hline \multirow{2}{*}{$\mathrm{LOG}(\mathrm{GEA})_{\mathrm{t}}$} & $0.127 * * *$ & $0.033 * * *$ & $0.066 * * *$ \\
\hline & $(2.480)$ & $(2.416)$ & (3.961) \\
\hline \multirow{2}{*}{$\mathrm{LOG}(\mathrm{GEH})_{\mathrm{t}}$} & $0.092 * * *$ & 0.004 & $0.017 * * *$ \\
\hline & (2.801) & $(0.961)$ & (2.624) \\
\hline \multirow{2}{*}{$\mathrm{LOG}(\mathrm{GEM})_{\mathrm{t}}$} & -0.028 & $0.040 * * *$ & $0.049 * * *$ \\
\hline & $(-0.588)$ & (3.489) & $(3.390)$ \\
\hline \multirow{2}{*}{$\mathrm{LOG}(\mathrm{DAU})_{\mathrm{t}}$} & $-0.512 * * *$ & $0.142 * * *$ & $0.088 * * *$ \\
\hline & $(-10.65)$ & (6.985) & (4.577) \\
\hline \multirow{2}{*}{$\mathrm{LOG}(\mathrm{FDI})_{\mathrm{t}}$} & $0.147 * * *$ & $0.016 * * *$ & $0.027 * * *$ \\
\hline & $(10.216)$ & (3.870) & $(5.546)$ \\
\hline \multirow{2}{*}{$\mathrm{OPN}_{\mathrm{t}}$} & 0.007 & $-0.010 * *$ & -0.008 \\
\hline & $(0.340)$ & $(-2.035)$ & $(-1.347)$ \\
\hline \multirow{2}{*}{$\mathrm{C}$} & $22.249 * * *$ & $28.989 * * *$ & $23.442 * * *$ \\
\hline & (14.564) & (26.111) & (22.085) \\
\hline R-squared & 0.948 & 0.997 & 0.791 \\
\hline F-statistic & 377.071 & 2872.229 & 78.295 \\
\hline
\end{tabular}

Berdasarkan Tabel 2 pengeluaran pemerintah untuk pendidikan, pengeluaran pemerintah untuk pertanian, dana alokasi umum dan investasi asing langsung memiliki pengaruh terhadap pertumbuhan ekonomi di daerah untuk model none effect, model fixed effect maupun model random effect. Sedangkan Opini Badan Pemeriksa Keuangan terhadap laporan keuangan pemerintah daerah hanya signifikan di model fixed effect, sedangkan pengeluran pemerintah daerah untuk kesehatan tidak signifikan dalam model fixed effect. Variable jumlah penduduk miskin tidak memiliki pengaruh terhadap pertumbuhan ekonomi daerah dalam model random effect. 


\section{Buletin Ekonomi}

Setelah hasil None Effect, Fixed Effect dan Random Effect diperoleh, selanjutnya dilakukan uji pemilihan Model. Untuk memilih model yang paling tepat dalam mengelola data panel, terdapat beberapa pengujian yang dapat dilakukan; Chow test adalah pengujian statistik untuk menentukan model Fixed Effect atau Common effect paling tepat digunakan dalam mengestimasi data panel. Sedangkan Hausman test adalah pengujian statistik untuk memilih apakah model Fixed Effect atau Random Effect yang paling tepat digunakan. Jika hasil Chow test dan Hausman test tidak konsisten perlu dilakukan pengujian untuk menentukan apakan Fixed effect atau Random effect yang akan dipilih, maka perlu melakukan uji Langrange Multiplier (LM) yang digunakan untuk memilih antara model Common Effects atau model Random Effects. Hasil pengujian Chow dan Hausman menetapkan model terbaik adalah Fixed Effect Model, dan pengujian asumsi klasik untuk model tersebut tidak mengadung adanya multikolinearitas dan heteroskedastisitas.

Berdasarkan Tabel 3 jumlah penduduk miskin memiliki pengaruh negative terhadap pertumbuhan ekonomi untuk model 1, model 2 maupun model 3. Koefisien jumlah penduduk miskin sebesar -0,292 pada model 1, artinya kenaikan jumlah penduduk miskin sebesar 1 persen akan menurunkan pertumbuhan ekonomi daerah sebesar 0,292 persen. Jumlah penduduk miskin menjadi salah satu penghambat pertumbuhan ekonomi. Untuk mengatasi jumlah penduduk miskin pemerintah pusat dan pemerintah daerah harus meningkatkan relevansi arah kebijakan, program dan alokasi anggaran pemerintah daerah terhadap kebutuhan intervensi penanggulangan kemiskinan. Meningkatkan konsolidasi belanja anggaran pemerintah daerah dengan anggaran pemerintah pusat, dan antar anggaran pemerintah darah untuk penanggulangan kemiskinan. Memberdayaan penduduk miskin melalui program pemberdayaan kelompok masyarakat miskin dengan pemberian modal usaha melalui program bantuan langsung pemberdayaan sosial untuk mengelola usaha ekonomi produktif dan bantuan kredit usaha rakyat dengan bunga pinjaman rendah.

Pengeluaran pemerintah daerah untuk pendidikan memiliki pengaruh positip terhadap pertumbuhan ekonomi, hal ini ditunjukan dengan nilai rata-rata koefisien untuk pengeluran untuk pendidikan sebesar 0,03 untuk model 1, model 2, model 3, dan model 4. Koefisien ini menunjukan bahwa kenaikan anggaran pendidikan sebesar 1 persen akan mendorong pertumbuhan ekonomi sebesar 0,03 persen. Walaupun anggaran pendidikan memiliki pengaruh positip tetapi pengaruhnya sangat kecil atau untuk menaikan 1 persen pertumbuhan dibutuhkan tambahan anggaran pendidikan 33 persen. Setiap tahun biaya pendidikan di Indonesia meningkat rata-rata $15 \%$ atau anggaran pendidikan menjadi penyumbangn inflasi di Indonesia. Peningkatan anggaran pendidikan di awali tahun 2005 dengan munculnya undang-undang guru dan dosen, dalam undang-undang disebutkan bahwa guru dan dosen yang tersertifikasi berhak memperoleh tunjangan sebesar gaji pokok. Peningkatan kesejahteraan guru dan dosen belum diimbangi dengan peningkatan kualitas guru dan dosen, dan akibatnya peningkatan anggaran pendidikan belum mendorong kualitas guru dan murid.

Pengeluaran pemerintah daerah untuk kesehatan tidak memiliki pengaruh terhadap pertumbuhan ekonomi, hal ini ditunjukan dengan nilai thitung yang sangat kecil untuk model 1, model 2, dan model 3. Sedangkan model 4 anggaran pemerintah daerah untuk kesehatan memiliki pengaruh positip terhadap pertumbuhan ekonomi, tetapi pengaruhnya sangat kecil. Setiap kenaikan 1 persen anggaran kesehatan hanya mendorong 0,019 persen pertumbuhan ekonomi, jika pertumbuhan ekonomi diharapkan tumbuh sebesar 1 persen maka anggaran pendidikan perlu dinaikan 50 persen. Budaya menjaga kesehatan di Indonesia masih rendah, sehingga jumlah penduduk yang menggunakan fasilitas rumah sakit semakin meningkat. Peningkatan penduduk yang menggunakan fasilitas kesehatan belum bisa ditutupi dengan anggaran pemerintah daerah untuk kesehatan. Peningkatan anggaran kesehatan belum 


\section{Buletin Ekonomi}

diimbangi dengan budaya menjaga kesehatan, sehingga menimbulkan pola hidup kurang sehat dan menyebabkan produktivitas belum maksimal.

Tabel 3

Regresi Model Fixed Effect

\begin{tabular}{|c|c|c|c|c|}
\hline \multirow{2}{*}{$\begin{array}{l}\text { Variable Dependent } \\
\text { LOG(GDRP })_{t}\end{array}$} & \multicolumn{4}{|c|}{ Fixed Effect Model } \\
\hline & Model 1 & Model 2 & Model 3 & Model 4 \\
\hline $\mathrm{LOG}(\mathrm{POV})_{\mathrm{t}}$ & $\begin{array}{r}-0.292 * * * \\
(-4.890)\end{array}$ & $\begin{array}{r}-0.371 * * * \\
(-6.345)\end{array}$ & $\begin{array}{r}-0.311 * * * \\
(-5.137)\end{array}$ & \\
\hline $\mathrm{LOG}(\mathrm{GEE})_{\mathrm{t}}$ & $\begin{array}{r}0.034 * * * \\
(4.727)\end{array}$ & $\begin{array}{r}0.034 * * * \\
(4.701)\end{array}$ & $\begin{array}{r}0.037 * * * \\
(5.085)\end{array}$ & $\begin{array}{r}0.029 * * * \\
(3.650)\end{array}$ \\
\hline $\mathrm{LOG}(\mathrm{GEH})_{\mathrm{t}}$ & $\begin{array}{r}0.005 \\
(0.961)\end{array}$ & $\begin{array}{r}0.009 \\
(1.397)\end{array}$ & $\begin{array}{r}0.004 \\
(0.744)\end{array}$ & $\begin{array}{r}0.019 * * * \\
(3.189)\end{array}$ \\
\hline $\mathrm{LOG}(\mathrm{GEA})_{\mathrm{t}}$ & $\begin{array}{r}0.033 * * * \\
(2.416)\end{array}$ & $\begin{array}{r}0.043 * * * \\
(3.301)\end{array}$ & $\begin{array}{r}0.037 * * * \\
(2.635)\end{array}$ & $\begin{array}{r}0.068 * * * \\
(4.432)\end{array}$ \\
\hline $\mathrm{LOG}(\mathrm{GEM})_{\mathrm{t}}$ & $\begin{array}{r}0.040 * * * \\
(3.489)\end{array}$ & $\begin{array}{r}0.056 * * * \\
(4.901)\end{array}$ & $\begin{array}{r}0.038 * * * \\
(3.293)\end{array}$ & $\begin{array}{r}0.065 * * * \\
(4.927)\end{array}$ \\
\hline $\mathrm{LOG}(\mathrm{DAU})_{\mathrm{t}}$ & $\begin{array}{r}0.142 * * * \\
(6.985)\end{array}$ & $\begin{array}{r}0.132 * * * \\
(6.869)\end{array}$ & $\begin{array}{r}0.152 * * * \\
(7.627)\end{array}$ & $\begin{array}{r}0.191 * * * \\
(9.088)\end{array}$ \\
\hline $\mathrm{LOG}(\mathrm{FDI})_{\mathrm{t}}$ & $\begin{array}{r}0.016 * * * \\
(3.870)\end{array}$ & & $\begin{array}{r}0.018 * * * \\
(4.409)\end{array}$ & \\
\hline $\mathrm{OPN}_{\mathrm{t}}$ & $\begin{array}{r}-0.010^{* *} \\
(-2.035)\end{array}$ & $\begin{array}{r}-0.016 * * * \\
(-3.056)\end{array}$ & & \\
\hline $\mathrm{C}$ & $\begin{array}{r}28.989 * * * \\
(26.111)\end{array}$ & $\begin{array}{r}29.982 * * * * \\
(26.702)\end{array}$ & $\begin{array}{r}28.811^{* * *} \\
(25.679)\end{array}$ & $\begin{array}{r}22.455 * * * \\
(54.609)\end{array}$ \\
\hline $\begin{array}{l}\text { R-squared } \\
\text { F-statistic }\end{array}$ & $\begin{array}{r}0.9979 \\
2872.229\end{array}$ & $\begin{array}{r}0,998 \\
33347\end{array}$ & $\begin{array}{l}0,99976 \\
2783.68\end{array}$ & $\begin{array}{r}0,9958 \\
1732,098\end{array}$ \\
\hline
\end{tabular}

( ) merupakan nilai t hitung

Pengeluaran pemerintah daerah untuk pertanian memiliki pengaruh positip terhadap pertumbuhan ekonomi, hal ini ditunjukan dengan nilai rata-rata koefisien untuk pengeluran pemerintah untuk pendidikan sebesar 0,05 untuk model 1, model 2, model 3, dan model 4 . Koefisen ini menunjukan bahwa kenaikan anggaran pertanian sebesar 1 persen akan mendorong pertumbuhan ekonomi sebesar 0,05 persen. Walaupun anggaran pertanian memiliki pengaruh positip tetapi pengaruhnya sangat kecil atau untuk menaikan 1 persen pertumbuhan dibutuhkan tambahan anggaran pertanian 20 persen. Karakteristik petani di Indonesia adalah lahannya kecil sehingga petani lebih banyak bercocok tanam secara individu. Dampak dari cara bercocok tanam yang lebih banyak dilakukan secara pribadi bukan kelompok menyebabkan anggaran pendampingan petani menjadi besar dibandingkan dengan berkelompok. Dengan belum berkelompoknya para petani kecil ini juga sulit memenuhi permintaan, serta risiko yang ditanggung menjadi sangat besar.

Pengeluaran pemerintah daerah untuk kelautan dan kemaritiman memiliki pengaruh positip terhadap pertumbuhan ekonomi, hal ini ditunjukan dengan nilai rata-rata koefisien untuk pengeluran pemerintah untuk kelautan dan kemaritiman sebesar 0,045 untuk model 1, model 2, model 3, dan model 4. Koefisien ini menunjukan bahwa kenaikan anggaran kelautan dan kemaritiman sebesar 1 persen akan mendorong pertumbuhan ekonomi sebesar 0,045 persen. Walaupun anggaran kelautan dan kemaritiman memiliki pengaruh positip tetapi 


\section{Buletin Ekonomi}

pengaruhnya sangat kecil atau untuk menaikan 1 persen pertumbuhan dibutuhkan tambahan anggaran pertanian 22,22 persen.

Rata-rata koefisien untuk pengeluran pemerintah daerah untuk pendidikan, kesehatan, pertanian, kelautan dan kemaritiman sebesar 0,028, artinya apabila anggaran tersebut dinaikan sebesar 1 persen mengakibatkan kenaikan pertumbuhan ekonomi sebesar 0,028 persen. Pengaruh anggaran pemerintah daerah untuk pendidikan, kesehatan, pertanian, kelautan dan kemaritiman memiliki pengaruh positip tetapi pengaruhnya sangat kecil atau untuk menaikan 1 persen pertumbuhan dibutuhkan tambahan anggaran (pendidikan, kesehatan, pertanian, kelautan dan kematiman) sebesar 35,7 persen.

Bagi hasil pemerintah pusat terhadap daerah yang diwujudkan dalam bentuk dana alokasi umum yang digunakan daerah untuk peningkatan pelayanan kepada masyarakat dalam rangka pelaksanaan otonomi daerah. Dana alokasi Umum memiliki pengaruh positip terhadap pertumbuhan ekonomi, hal ini ditunjukan dengan nilai rata-rata koefisien untuk dana alokasi umum sebesar 0,16 untuk model 1, model 2, model 3, dan model 4. Koefisien ini menunjukan bahwa kenaikan anggaran dana alokasi umum sebesar 1 persen akan mendorong pertumbuhan ekonomi sebesar 0,16 persen. Dana alokasi umum memiliki pengaruh positip dan pengaruhnya cukup besar atau untuk menaikan 1 persen pertumbuhan dibutuhkan tambahan anggaran dana alokasi umum sebesar 6,25 persen.

Untuk mengatasi tidak efektifnya anggaran pemerintah daerah dalam mendorong pertumbuhan ekonomi, pemerintah harus merubah penganggaran pendekatan tradisional menjadi penganggran pendekatan kinerja. Penganggaran kinerja disusun dengan orientasi output. Sistem ini menitikberatkan pada segi penatalaksanaan sehingga selain efisiensi penggunaan dana juga hasil kerjanya diperiksa. Tolok ukur keberhasilan sistem anggaran ini adalah performance atau prestasi dari tujuan atau hasil anggaran dengan menggunakan dana secara efisien. Dengan membangun suatu sistem penganggaran yang dapat memadukan perencanaan kinerja dengan anggaran tahunan akan terlihat adanya keterkaitan antara dana yang tersedia dengan hasil yang diharapkan.

Penanaman modal asing langsung memiliki pengaruh positip terhadap pertumbuhan ekonomi, hal ini ditunjukan dengan nilai rata-rata koefisien untuk pengeluran untuk penanaman modal asing langsung sebesar 0,018 untuk model 1, model 3. Koefisen ini menunjukan bahwa kenaikan penanaman modal asing langsung sebesar 1 persen akan mendorong pertumbuhan ekonomi sebesar 0,018 persen. Ini menunjukan bahwa peran penanaman modal asing di Indonesia terhadap penciptaan lapangan kerja sangat rendah, sehingga pengangguran tidak dapat teratasi dengan penanaman modal asing langsung dan akhirnya kontribusi terhadap pertumbuhan ekonomi rendah.

Opini Badan Pemeriksa Keuangan terhadap Laporan Keuangan Pemerintah Daerah memiliki pengaruh negatif terhadap pertumbuhan ekonomi. Tanda negative ini menunjukan bahwa rendahnya peringkat opini Badan Pemeriksa Keuangan akan menghambat pertumbuhan ekonomi. Opini Badan Pemeriksa Keuangan telah berkontribusi dalam memperbaiki transparansi dan akuntabilitas keuangan pemerintah. Pemimpin daerah memiliki kekuasaan atas pengelolaan anggaran daerah, tetapi dalam penggunaan anggaran harus digunakan untuk sebesar-besar kemakmuran rakyat. sehingga pengelolaannya harus tertib, ekonomis, efektif, transparan, dan bertanggung jawab dengan memperhatikan rasa keadilan dan kepatutan.

\section{KESIMPULAN}

Jumlah penduduk miskin menjadi salah satu penghambat pertumbuhan ekonomi. Untuk mengatasi jumlah penduduk miskin pemerintah pusat dan pemerintah daerah harus 


\section{Buletin Ekonomi}

meningkatkan relevansi arah kebijakan, program dan alokasi anggaran pemerintah daerah terhadap kebutuhan intervensi penanggulangan kemiskinan. Pengaruh anggaran pemerintah daerah untuk pendidikan, kesehatan, pertanian, kelautan dan kemaritiman memiliki pengaruh positip tetapi pengaruhnya sangat kecil. Untuk mengatasi tidak efektifnya anggaran pemerintah daerah dalam mendorong pertumbuhan ekonomi, pemerintah harus merubah penganggaran dengan pendekatan tradisional dengan penganggran pendekatan kinerja. Penganggaran kinerja disusun dengan orientasi output. Sistem ini menitikberatkan pada segi penatalaksanaan sehingga selain efisiensi penggunaan dana juga hasil kerjanya diperiksa. Tolok ukur keberhasilan sistem anggaran ini adalah performance atau prestasi dari tujuan atau hasil anggaran dengan menggunakan dana secara efisien. Dengan membangun suatu sistem penganggaran yang dapat memadukan perencanaan kinerja dengan anggaran tahunan akan terlihat adanya keterkaitan antara dana yang tersedia dengan hasil yang diharapkan.

Bagi hasil pemerintah pusat terhadap daerah yang diwujudkan dalam bentuk dana alokasi umum yang digunakan daerah untuk peningkatan pelayanan kepada masyarakat dalam rangka pelaksanaan otonomi daerah. Dana alokasi Umum memiliki pengaruh positip terhadap pertumbuhan ekonomi. Dana Alokasi Umum untuk beberapa daerah akan berimbas pada pembangunan dan pertumbuhan ekonomi regional di daerah tersebut dan pada akhirnya akan mempengaruhi pertumbuhan ekonomi nasional. Jika pengelolaan dana alokasi umum tidak baik atau dihapuskan dari pemerintah pusat maka akan berimbas negative terhadap stabilitas keuangan daerah, stabilitas keuangan daerah yang terganggu ini akan berimbas pada pelaksanaan program-program pemerintah daerah dalam rangka peningkatan kesejahteraan masyarakat yang akan terganggu pula. Imbas lain adalah terganggunya program-program pemerintah daerah yang bertujuan utnuk meningkatkan pelayanan public atau insfrastruktur yang dapat menjadi pemacu rendahnya pertumbuhan ekonomi ragional maupun ekonomi nasional. Penanaman modal asing lansung memiliki pengaruh positip terhadap pertumbuhan ekonomi, tetapi pengaruhnya sangat kecil. Ini menunjukan bahwa peran penanaman modal asing di Indonesia terhadap penciptaan lapangan kerja sangat rendah, sehingga pengangguran tidak dapat teratasi dengan penanaman modal asing langsung dan akhirnya kontribusi terhadap pertumbuhan ekonomi rendah. Pemerintah harus selektif dalam memilih investasi asing langsung, terutama invesitasi asing yang berdampak pada pengurangan pengangguran. Investasi yang diperbolehkan adalah investasi yang padat karya dan menghasilkan ouput sebagai pengganti barang impor.

\section{DAFTAR PUSTAKA}

Abala, D.O., 2014. Foreign direct investment and economic growth: an empirical analysis of Kenyan data. DBA Africa Management Review, 4(1), pp.62-83.

Agustine, A.D., 2014. Pengembangan Sektor Kelautan dan Perikanan Untuk Meningkatkan Pendapatan Asli Daerah (Studi di Dinas Kelautan dan Perikanan Kabupaten Banyuwangi). Jurnal Administrasi Publik, 2(2), pp.276-280.

Al-Shatti, A.S., 2014. The Impact of Public Expenditures on Economic Growth in Jordan. International Journal of economics and Finance, 6(10), p.157.

Armas, E.B., Osorio, C.G., Moreno-Dodson, B. and Abriningrum, D.E., 2012. Agriculture public spending and growth in Indonesia. The World Bank.

Arsyad, L., 2014. Ekonomi pembangunan. 


\section{Buletin Ekonomi}

Basri, F.H., 1995. Perekonomian Indonesia menjelang abad XXI: distorsi, peluang, dan kendala. Erlangga.

Chidinma, E. and Kemisola, C.O., 2012. Government Expenditure on Agriculture and Economic Growth in Nigeria. International Journal of Science and Research, 3(358).

Dada, M.A., 2013. Composition effects of government expenditure on private consumption and output growth in Nigeria: A single-equation error correction modelling. Romanian Journal of Fiscal Policy (RJFP), 4(2), pp.18-34.

Dao, M.Q., 2012. Population and economic growth in developing countries. International Journal of Academic Research in Business and Social Sciences, 2(1), p.6.

Grabova, P., 2014. Corruption impact on Economic Growth: An empirical analysis. Journal of Economic Development, Management, IT, Finance, and Marketing, 6(2), p.57.

Gujarati, D.N., 2003. Basic Econometrics, McGraw-Hill. New York.

Hsiao, C., 2014. Analysis of panel data (No. 54). Cambridge university press.

Hemming, R., Mahfouz, S. and Kell, M., 2002. The effectiveness of fiscal policy in stimulating economic activity--a review of the literature (Vol. 2). International Monetary Fund.

Huda, H.M., Purnamadewi, Y.L. and Firdaus, M., 2015. Industrialisasi Perikanan Dalam Pengembangan Wilayah di Jawa Timur. Tataloka, 17(2), pp.99-112.

Indra, B., 2006. Akuntansi Sektor Publik. Jakarta: Erlangga.

Lamartina, S. and Zaghini, A., 2011. Increasing public expenditure: Wagner's law in OECD countries. German Economic Review, 12(2), pp.149-164.

Maddala, G.S. and Lahiri, K., 1992. Introduction to econometrics (Vol. 2). New York: Macmillan.

Mangkoesoebroto, G., 2001. Ekonomi publik. BPFE, Yogyakarta.

Manik, R.E. and Hidayat, P., 2010. Analisis kausalitas antara pengeluaran pemerintah dan pertumbuhan ekonomi Sumatera utara (Metode Cointegration Test dan Granger causality Test). Jurnal Keuangan \& Bisnis Program Studi Magister Manajemen Sekolah Tinggi Ilmu Ekonomi Harapan, 2(1), pp.46-56.

Mauro, P., 1995. Corruption and growth. The quarterly journal of economics, 110(3), pp.681712.

Mehanna, R.A., 2003. The Temporal Causality between Investment and Growth in Developing Economies. Journal of Business and Economics Research, 1(3), p.85.

Mursidah, M., Effendi, M. and Zaini, A., 2017. Analisis Dampak Penggunaan Anggaran Sektor Pertanian Terhadap Pertumbuhan Ekonomi Sektor Pertanian di Provinsi Kalimantan Timur. Jurnal Pertanian Terpadu, pp.58-69.

Muthui, J.N., Kosimbei, G., Maingi, J. and Thuku, G.K., 2013. The Impact of Public Expenditure Components on Economic Growth in Kenya 1964-2011. International Journal of business and social Science, 4(4).

Muti'ah. 2017. The Effect of Regional Revenue, Revenue Sharing Fund, General Allocation Fund and Special Allocation Fund on Regional Economic Growth (Empirical Study 


\section{Buletin Ekonomi}

In the 33 provinces in Indonesia Year 2011-2014), Research Journal of Finance and Accounting. Vol.8. No.8. 2017.

Novianti, T., Rifin, A., Panjaitan, Dian V., and Sri Retno WN. 2014. The Infrastructure's Influence on the Asean Countries' Economic Growth, Journal of Economics and Development Studies December 2014, Vol. 2. N. 4.

Nworji I. D., Okwu A. T., Obiwuru T. C. \& Nworji L. O. (2012). "Effects of Public Expenditure on Economic Growth in Nigeria: A Disaggregated Time Series Analysis".International Journal of Management Sciences and Business Research, Vol. 1 , Issue 7.

Oloni, E.F. and Olabisi, A.S., 2012. Composition of public expenditure and economic growth in Nigeria. Journal of Emerging Trends in Economics and Management Sciences, 3(4), pp.403-407.

Oyinbo, O., Zakari, A. and Rekwot, G.Z., 2013. Agricultural budgetary allocation and economic growth in Nigeria: implications for agricultural transformation in Nigeria. Journal of Sustainable Development, 10(1), pp.16-27.

Rustan, A., 2013. Desentralisasi Fiskal dan Pertumbuhan Ekonomi, serta Kaitannya dengan Otonomi Daerah. Jurnal Borneo Administrator, 9(3).

Soetrisno, P.H., 1981. Dasar-dasar ilmu keuangan negara. Bagian Penerbitan, Fakultas Ekonomi, Universitas Gadjah Mada.

Sugiyono, S.U.P., 2005. Bandung. Affabeta, $C V$.

Sylwester, K., 2000. Income inequality, education expenditures, and growth. Journal of development economics, 63(2), pp.379-398.

Tajuddin, I., Hasanuddin, B. and Rahmatia, P.U., 2014. The Effects Of General Allocation Funds, Special Allocation Funds And Revenue-Sharing Funds On Investment, Economic Growth, Economic Structure, And Employment. University Of Hassanudin, Indonesia.

Tajuddin, I., Hasanuddin, B. and Rahmatia, P.U., 2014. The Effects Of General Allocation Funds, Special Allocation Funds And Revenue-Sharing Funds On Investment, Economic Growth, Economic Structure, And Employment. University of Hassanudin, Indonesia.

Todaro, M.P., 2000. Economic Development, New York, Addition Wesley Longman. 